The Bryologist 107(1), pp. 28-40

Copyright (C) 2004 by the American Bryological and Lichenological Society, Inc.

\title{
Molecular, Morphological, and Phytochemical Evidence for a Broad Species Concept of Plagiochila bifaria (Hepaticae)
}

\author{
Jochen Heinrichs, Henk Groth, Melanie Lindner, and Kathrin Feldberg \\ Department of Systematic Botany, Albrecht von Haller Institute of Plant Sciences, Georg August University, Untere \\ Karspüle 2, D-37073 Göttingen, Germany; e-mail: jheinri@gwdg.de \\ DAVID S. RYCROFT \\ Department of Chemistry, University of Glasgow, Glasgow G12 8QQ, Scotland, U.K. e-mail: D.Rycroft@chem. \\ gla.ac.uk
}

Abstract. Debate over the synonymy of the European Plagiochila killarniensis and the Neotropical P. bifaria of P. sect. Arrectae has focused on differences in secondary metabolite composition. The broad morphological species concept of $\mathrm{P}$. bifaria proposed in recent papers has now been tested by comparing nrDNA ITS1 and ITS2 sequences of $\mathrm{P}$. bifaria populations encompassing several different morpho- and chemotypes from the British Isles, Tenerife, Costa Rica, Brazil, Ecuador, and Bolivia, with sequences of other species of P. sects. Arrectae, Rutilantes, and Fuscoluteae. Phylogenetic analyses demonstrate that specimens of $\mathrm{P}$. bifaria form a well supported clade within Plagiochila sect. Arrectae. Sequences of P. bifaria from the British Isles, Tenerife, and Ecuador, representing the "methyl everninate" chemotype, form a well supported subclade within the P. bifaria clade. Sequences of specimens from Costa Rica, Brazil, and Bolivia are placed in the basal part of the P. bifaria clade. The data support a broad species concept of $\mathrm{P}$. bifaria. The different chemotypes do not warrant distinct taxonomic ranks. Plagiochila centrifuga and $\mathrm{P}$. compressula are treated as new synonyms of $\mathrm{P}$. bifaria.

Keywords. Hepatics, internal transcribed spacer, nuclear ribosomal DNA, phylogeny, phylogeography, phytochemistry, Plagiochila bifaria.

Morphological species concepts are still widely used in bryophyte taxonomy. Classification within morphologically stable groups is usually unproblematic. When many phenotypes exist, definition of morphospecies is more difficult and is often the subject of controversy. Notorious in this respect is the liverwort genus Plagiochila (Dumort.) Dumort. Morphospecies of Plagiochila are distinguished by considerable gametophytic variation such as leaf shape, dentition, and cell size, making it sometimes impossible to find two morphologically fully identical populations. Many early bryologists tried to cope with the bewildering diversity in Plagiochila by creating numerous binomials, often based on single collections (e.g., Gottsche 1863-1867; Spruce 1884-1885; Stephani 1902-1905) from limited geographic ranges. In recent revisions (e.g., Heinrichs 2002), acceptance of broader morphological variation has often lead to range extensions of assumed endemics.

The origin and relationships of the Atlantic European Plagiochila flora have been unclear for a long time. However, recent investigations (Groth et al. 2002, 2003; Heinrichs 2002; Heinrichs et al. 1998a,b, 2000, 2002b,c; Rycroft et al. 2001, 2002) have demonstrated that the species forming the majority of Plagiochila taxa from Atlantic Europe are close to or conspecific with species from tropical America.

Heinrichs et al. $(1998 a, b)$ presented morphological evidence for the conspecificity of Plagiochila killarniensis Pearson, which was described from material gathered in the British Isles, and P. bifaria (Sw.) Lindenb., whose type originates from Jamaica, and accepted a broad morphological variation for the taxon. Rycroft et al. (1999); however, found differences between the lipophilic secondary metabolite profile of $P$. bifaria populations from Europe and one report from tropical America (Asakawa \& Inoue 1987). They retained "both names ... for the purposes of [their] paper," purely as a convenient device to simplify discussion of the results with no intention of expressing a taxonomic opinion. However, Söderström et al. (2002) cited these chemical differences when airing doubts over the proposed synonymy.

Heinrichs (2002) analyzed ITS sequence variation of 40 Plagiochila species and demonstrated that $P$. bifaria populations from Ecuador and Tenerife form a monophyletic lineage. Rycroft (2003) 
TABLE 1. Geographic origins, vouchers (collector and collection number), and GenBank/EMBL accession numbers (bold for new sequences) of the taxa investigated. Vouchers are deposited at GOET unless indicated otherwise; duplicates of those marked with an asterisk (*) were distributed in "Bryophyta Exsiccata Generis Plagiochilae" (B.E.G.P; Heinrichs \& Anton 2001).

\begin{tabular}{|c|c|c|c|}
\hline Taxon & Origin & Voucher & $\begin{array}{l}\text { Accession } \\
\text { number }\end{array}$ \\
\hline P. aerea Taylor & Costa Rica & Heinrichs et al. 4321, B.E.G.P. 95 & AJ422028 \\
\hline P. bidens Gottsche & Brazil & Gradstein 5378 (G) & AF539458 \\
\hline P. bifaria (Sw.) Lindenb. & Tenerife & Drehwald 3922 & AJ413173 \\
\hline P. bifaria (Sw.) Lindenb. & British Isles & Rycroft 01014 & AY453387 \\
\hline P. bifaria (Sw.) Lindenb. & Brazil & Costa \& Gradstein 3805 & AY 453388 \\
\hline P. bifaria (Sw.) Lindenb. & Costa Rica & Heinrichs et al. 4394 & AY453389 \\
\hline P. bifaria (Sw.) Lindenb. & Ecuador & Holz EC-01-113 & AJ422011 \\
\hline P. bifaria (Sw.) Lindenb. & Ecuador & Holz EC-01-416 & AJ422010 \\
\hline P. bifaria (Sw.) Lindenb. & Bolivia & Heinrichs et al. 4402 & AY453390 \\
\hline P. cuneata Lindenb. \& Gottsche & Bolivia & Heinrichs et al. 4093 & AF539460 \\
\hline P. deflexa Mont. \& Gottsche & Costa Rica & *Heinrichs et al. 4160 , B.E.G.P. 10 & AJ416083 \\
\hline P. exigua (Taylor) Taylor & Ireland & Hakelier s.n. & AF539461 \\
\hline P. fuscolutea Taylor & Costa Rica & *Heinrichs et al. 4400 , B.E.G.P. 148 & AJ416086 \\
\hline $\begin{array}{l}\text { P. gymnocalycina (Lehm. \& Lindenb.) } \\
\text { Mont. }\end{array}$ & Bolivia & $\begin{array}{l}\text { *Drehwald \& Drehwald } 4729 \text {, } \\
\text { B.E.G.P. } 153\end{array}$ & AY390531 \\
\hline P. patzschkei Steph. & Ecuador & Holz EC-01-389 & AJ422018 \\
\hline P. punctata (Taylor) Taylor & British Isles & Rycroft 01013 & AJ413174 \\
\hline P. retrorsa Gottsche & Costa Rica & Heinrichs et al. 4154 & AJ422021 \\
\hline$P$. rutilans Lindenb. var. rutilans & Bolivia & Groth 101 & AJ416081 \\
\hline P. spinulosa (Dicks.) Dumort. & British Isles & Rycroft 01012 & AJ413175 \\
\hline P. spinulosa (Dicks.) Dumort. & Belgium & Dauphin et al. 3811 & AY275173 \\
\hline P. steyermarkii H. Rob. & Venezuela & Steyermark et al. 112531 & AF539465 \\
\hline$P$. stricta Lindenb. & Ecuador & Holz EC-01-478 & AJ416647 \\
\hline$P$. stricta Lindenb. & Costa Rica & Heinrichs et al. 4401 & AJ416646 \\
\hline P. stricta Lindenb. & Tenerife & Drehwald 3920 & AJ416649 \\
\hline$P$. stricta Lindenb. & Tenerife & Rycroft 01071 & AJ416648 \\
\hline P. trichostoma Gottsche & Costa Rica & *Heinrichs et al. 4324 , B.E.G.P. 56 & AJ416028 \\
\hline
\end{tabular}

found the lipophilic secondary metabolites of one of the Ecuadorian specimens essentially similar to those of Irish material from near the type locality of $P$. killarniensis (and to those of European, including Macaronesian, material in general). In order to further verify the $P$. bifaria synonymy proposed by Heinrichs et al. $(1998 a, b)$ we now add $P$. bifaria sequences from Europe and Central and South America (Andes and Southeastern Brazil) that extend coverage to all regions of the range and that include several different morpho- and chemotypes.

\section{Materials AND Methods}

Morphology.-This investigation is based on specimens from the herbaria F, FLAS, G, GOET, JE, INB, LPB, MO, NY, $\mathrm{RB}, \mathrm{S}$, STR, U, and $\mathrm{W}$.

DNA extraction.-Plant tissue from the distal portions of a few shoots were selected from Costa \& Gradstein 3805, Heinrichs et al. 4402, Heinrichs et al. 4394, and Rycroft 01014 (all GOET). Total genomic DNA was extracted with Invisorb Spin Plant Mini Kit (Invitek).

PCR-amplification. - The 5'-primer Hep2f (5'-GAG TCA TCA GCT CGC GTT GAC-3') (Groth et al. 2002) and the $3^{\prime}$ primer HepCr (TCT CCA GAC TAC AAT TCG CAC A) (Groth et al. 2003) were used to amplify the internal transcribed spacer (ITS) region of the nuclear ribosomal DNA containing ITS1, ITS2, and the 5.8S gene. The polymerase chain reaction (PCR: Saiki et al. 1988) was performed in a total volume of $50 \mu 1$, containing one unit Taq-DNA-polymerase (SilverStar, EuroGenTech), 5 $\mu 1$ Taq polymerase reaction buffer (EuroGenTech), $2 \mu 1$ $\mathrm{MgCl}_{2}(50 \mathrm{mM}), 1 \mu \mathrm{dNTP}-\mathrm{mix}$ (10 mM, MBI Fermentas), $2 \mu l$ dimethylsulfoxide, $1 \mu l$ each of forward and reverse primer $(10 \mathrm{mM})$, and $1 \mu l$ template. PCR amplification was carried out using the following program: 120 sec. initial denaturation at $92^{\circ} \mathrm{C}$, followed by 30 cycles of $60 \mathrm{sec}$. denaturation at $92^{\circ} \mathrm{C}, 50 \mathrm{sec}$. annealing at $51^{\circ} \mathrm{C}$, and $90 \mathrm{sec}$. elongation at $72^{\circ} \mathrm{C}$. Final elongation was carried out in one step $\left(10 \mathrm{~min} .72^{\circ} \mathrm{C}\right)$. Sequencing was carried out on an ABI 3100 capillary sequencer using the BigDye Terminator Cycle Sequencing v2.0 kit (PE Biosystems).

Phylogenetic analyses. - 22 nrITS Plagiochila sequences of representatives of Plagiochila sects. Arrectae Carl, Fuscoluteae Carl, and Rutilantes Carl from previous studies (Groth et al. 2002, 2004; Heinrichs 2002; Heinrichs et al. 2002a) as well as four new nrITS sequences of Plagiochila bifaria were used for the phylogenetic analyses (Table 1). The 26 ITS1 and ITS2 sequences were manually aligned using BioEdit version 5.0.9 (Hall 1999). The resulting dataset that comprises 608 putatively homologous sites is available from JH. Previous analyses (e.g., Groth et al. 2002; Heinrichs 2002) demonstrated the sister relationship of Plagiochila sects. Arrectae and Rutilantes. Hence, Plagiochila aerea Taylor and P. fuscolutea Taylor ( $P$. sect. Fuscoluteae) were assigned to the outgroup in the phylogenetic analyses.

Phylogenetic trees of the above data set were inferred using distance (neighbor-joining; NJ), maximum parsimony (MP), and maximum likelihood (ML) criteria as im- 
plemented in PAUP* version $4.0 \mathrm{~b} 10$ (Swofford 2000). To decide on the evolutionary model that fits the data best, the program Modeltest 3.06 (Posada \& Crandall 1998) was used, which employs two statistics: the likelihood ratio test (LRT) and the Akaike information criterion (AIC, Akaike 1974). Based on the results of the tests, the model selected by the hierarchical LRT was the HKY85 model (Hasegawa et al. 1985) with gamma shape parameter (G) for among site variation calculated from the data set $(\mathrm{HKY} 85+\mathrm{G})$. Maximum likelihood analyses (with the parameters of the $\mathrm{HKY} 85+\mathrm{G}$ model) were implemented as heuristic searches with 10 random-addition sequence replicates.

The confidence of branching was assessed using 200 bootstrap resamplings in ML analysis (using the HKY $85+\mathrm{G}$ model) and 1,000 resamplings in distance (neighbor-joining method using the HKY85+G model) and unweighted MP (heuristic searches with 10 random addition sequence replicates) of the data set (Felsenstein 1985).

NMR and GC-MS profiling.-The methods used to determine and quantify the components of deuterochloroform extracts of the liverwort specimens were as described previously (Rycroft et al. 2002).

\section{RESUlts}

The maximum likelihood analysis produced a single tree in which the 24 ingroup sequences are resolved into two well supported lineages that correspond to Plagiochila sects. Arrectae Carl and Rutilantes Carl (Fig. 1). Branch length variation within the Arrectae is less than in the Rutilantes. Monophyly of sequences from different $P$. spinulosa and $P$. stricta populations (Groth et al. 2003; Rycroft et al. 2002) is confirmed, but only the P. spinulosa clade is well supported by bootstrap analyses.

All seven Plagiochila bifaria sequences form a robust clade within the Arrectae lineage. Lengths of the $P$. bifaria sequences vary between 330 and $353 \mathrm{bp}$ (ITS 1) and 246-255 bp (ITS 2). The length variation is caused mainly by an indel at the end of ITS 1 (Fig. 2) that until now was known only from representatives of $P$. sect. Rutilantes (Groth et al. 2002; Heinrichs et al. 2002a). The same indel occurs in two of the $P$. bifaria sequences (specimens from Bolivia and Costa Rica), whereas the other $P$. bifaria sequences lack only parts of this sequence sector.

The sequences from the British, Tenerife, and Ecuadorian $P$. bifaria specimens are placed in a well supported subclade. They represent what might be called the 'methyl everninate chemotype' (see Rycroft 2003). Sequences of $P$. bifaria from Bolivia, Brazil, and Costa Rica comprise a paraphyletic grade at the base of the clade.

The ITS sequences of Plagiochila bifaria have been generated from phenotypes with extremely different leaf dentition and leaf shape (see Figs. 35). The morphological differences are not reflected in the molecular topology: the Ecuadorian specimen (Holz EC-01-113) has leaves with very long, elongate triangular to ciliate teeth (Figs. 3F-G). The Costa Rican specimen has even longer, more slender teeth with an up to 12 cells long uniseriate part (Figs. 4A,E). The Bolivian specimen (Fig. 5) as well as the British and Tenerife material (Fig. $3 \mathrm{H})$ have rather short, triangular to elongate triangular teeth. The Ecuadorian specimen (Holz EC-O1416-Figs. 3D,E) and the Brazilian specimen (Figs. $4 \mathrm{~B}, \mathrm{~F})$ are somewhat intermediate between the above extremes.

A similar situation is valid for the dentition of the perianth mouth. The Ecuadorian specimens (Holz, EC-01-113 and 416) that were collected on the same mountain slope in southern Ecuador, show considerable variation in the length of the perianth teeth (Figs. 3D,G). The Costa Rican plant has strongly fragmenting leaves that disintegrate even in the field when the moistened plants are touched (Figs. 4A,E). The other specimens have moderately fragmenting leaves at most.

The Bolivian plant, resolved at the base of the $P$. bifaria clade, is distinguished by its robust habit and the numerous lateral intercalary branches that form a pinnate habit (Fig. 5D). This phenotype is common in the Bolivian Andes at elevations above $2,500 \mathrm{~m}$. The apical leaf teeth of the plants sequenced are at best slightly larger than the triangular teeth of the ventral leaf margin (Figs. 5A,B). However, this phenotype often grows intermingled with plants with elongate-triangular teeth to ciliate teeth and larger apical teeth. The numerous branches are not present in all robust plants and furthermore occur within some delicate $P$. bifaria phenotypes.

The phytochemical data are presented in Table 2 and the chemical structures in Fig. 6. The data demonstrate a close relationship of the lipophilic secondary metabolite distributions in specimens (viii), Tenerife, and (ix), Ecuador. These two profiles are similar to those of Scottish and Azores material (Rycroft et al. 1999). Madeiran material gives similar results (Rycroft 1999), as does a range of material from the British Isles. Compounds $\mathbf{7}$ and $\mathbf{1 0}$ are still unknown, but have been correlated with singlets for methyl groups in the ${ }^{1} \mathrm{H}$ NMR spectra at $\delta 0.757$ and $0.745 \mathrm{ppm}$, respectively. The three Bolivian specimens (i-iii) display a different and rather uniform profile of compounds that is suggestive of some examples of $P$. retrorsa Gottsche (Rycroft et al. 2001). Two of the Brazilian specimens, (iv) and (vi), and the Costa Rican, (vii), contain a similar range of compounds, but the profiles are distinct. The profile of the Brazilian specimen (v) is very different and, at first sight, most of the compounds present seem to be unrelated to most of those in Table 2. Compound 11a appears to be new but was not isolated. The structure is based on anal- 


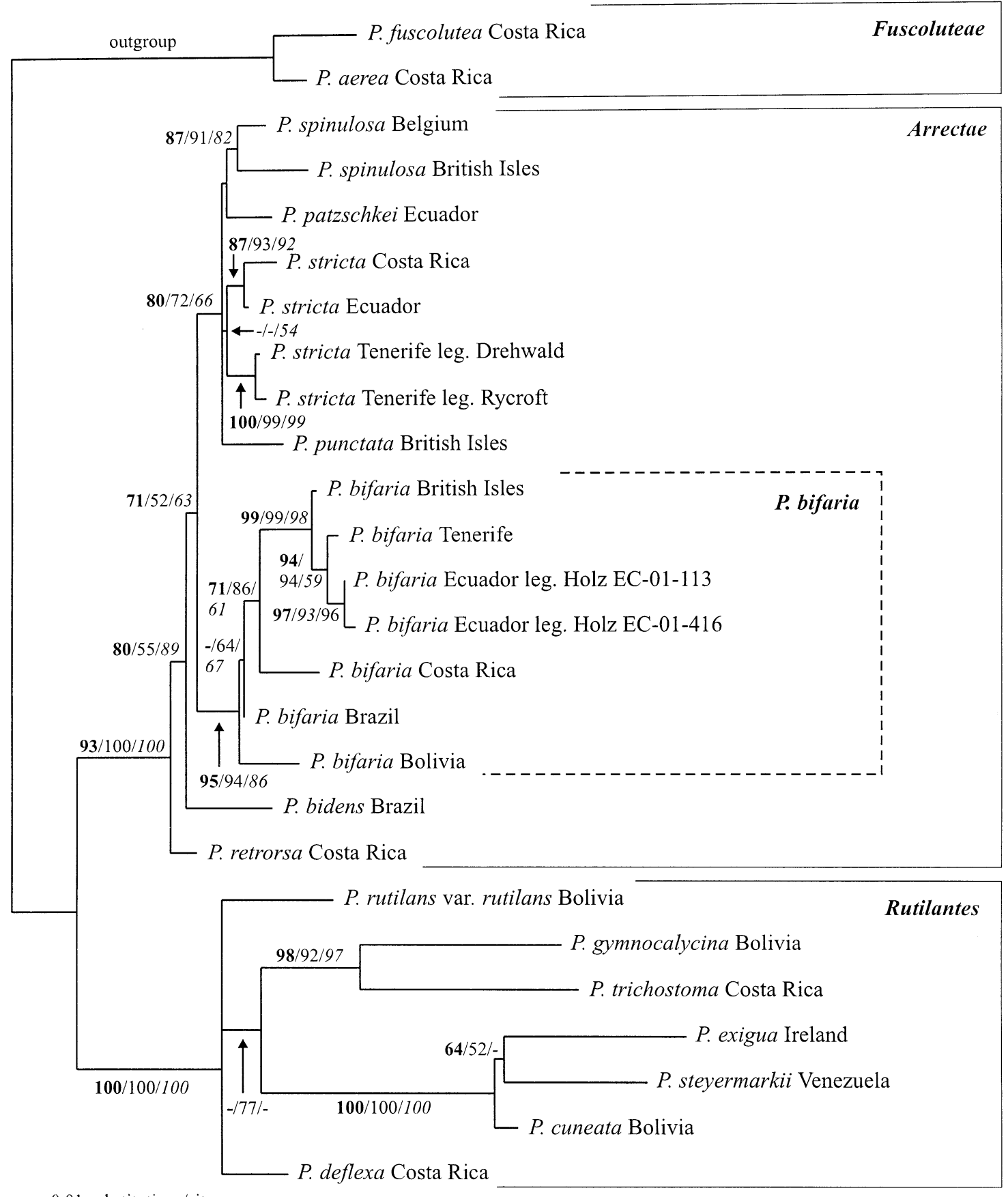

- 0.01 substitutions/site

FIGURE 1. Molecular phylogeny of Plagiochila species based on nrDNA ITS1- and ITS2-sequence comparisions using 608 aligned positions. The rooted tree resulted from a maximum likelihood analysis of 26 sequences (including the outgroup sequences), using the HKY $85+\mathrm{G}$ model with estimated gamma shape $(\mathrm{G}=0.52)$ and transition/transversion ratio $(\mathrm{Ti} / \mathrm{Tv}=1.88)$, calculated as the best model by Modeltest 3.06 (Posada \& Crandall 1998); bootstrap percentage values $(>50 \%)$ were determined for maximum likelihood (using HKY $85+\mathrm{G}$; bold), unweighted maximum parsimony (not bold), and neighbor-joining (HKY85+G; italics, not bold) methods. 

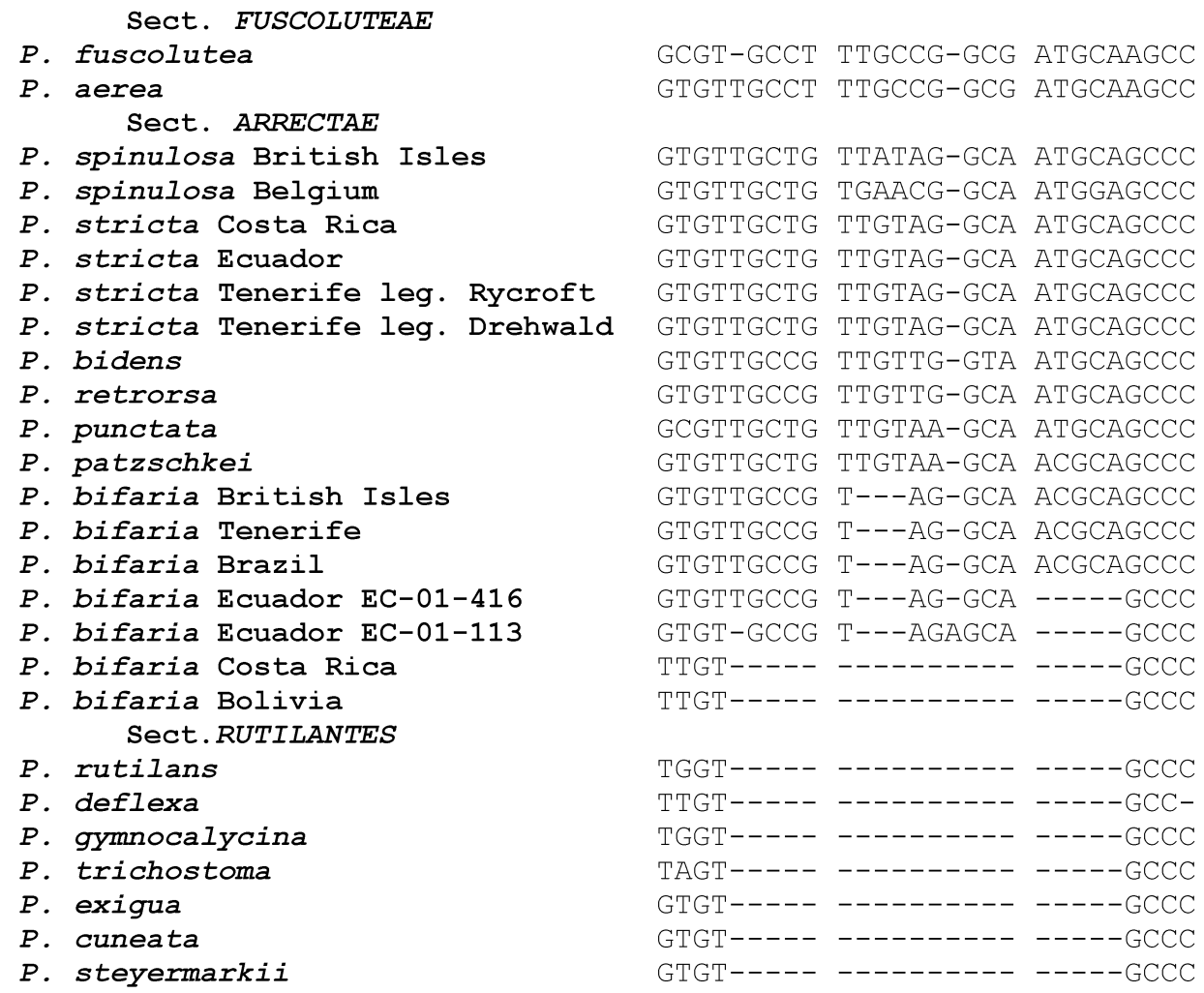

FIGURE 2. ITS sequence variation of Plagiochila. Part of the alignment of the 3 'end of ITS1.

ysis of signals in the ${ }^{1} \mathrm{H}$ NMR spectrum and GCMS experiments; correlations between the two types of data were inferred from relative intensities. GC-MS established a molecular mass of 246; the base peak at $m / z, 121$ together with NMR signals at $\delta 3.792$ (methoxyl) and $7.11 \mathrm{ppm}$ (half of $\mathrm{AA}^{\prime} \mathrm{BB}^{\prime}$ system) demonstrated the presence of a 4-methoxybenzyl moiety. An $[\mathrm{M}-58]^{+}$ion is characteristic of a methyl ketone undergoing fragmentation beta to the carbonyl group with transfer of a proton in a McClafferty rearrangement. It may be deduced that compound 11a is a 9-(4-methoxyphenyl)non6-en-2-one (a 4- or 5-ene would not undergo the McClafferty rearrangement and a 7-ene would require the presence of ${ }^{1} \mathrm{H}$ NMR signals in a region of the spectrum that is in fact clear). There are signals in the ${ }^{1} \mathrm{H}$ NMR spectrum [ 83.790 (methoxyl) and $7.08 \mathrm{ppm}$ (half of $\mathrm{AA}^{\prime} \mathrm{BB}^{\prime}$ system)] consistent with a second compound that contains a 4-methoxybenzyl moiety, at a level (ca $12 \mathrm{~mol} \mathrm{t}^{-1}$ ) slightly less than that of compound 11a. The corresponding peak in the GC-MS (at a slightly longer retention time) with the base peak at $\mathrm{m} / \mathrm{z}, 121$ shows that the molecular mass of this compound, 11b, is 244 . This compound therefore has one double bond more than 11a and is deduced to be a 9-(4-methoxyphenyl)nona-3,6-dien-2-one (the assignment of the double bonds is based on the absence of signals that would be required by alternative possibilities). There are another three peaks in the GC-MS with similar TIC integrals. The mass spectra of these compounds are consistent with the following partial structures (in order of increasing retention time): 11c: 9-(dimethoxyphenyl)non-6-en-2-one (molecular mass 276, base peak 151); 11d: 9-(dimethoxyphenyl)nona-3,6-dien-2-one (molecular mass 274 , base peak 151); 11e: 9-(hydroxydimethoxyphenyl)nona-3,6-dien-2-one (molecular mass 290, base peak 124). An additional peak of similar intensity appears with the longest retention time in the GCMS when the extract is acetylated and is apparently derived from 11f: 9-(dihydroxymethoxyphenyl)nona-3,6-dien-2-one (molecular mass 276, base peak 124). The even-numbered $\mathrm{m} / \mathrm{z}$ of the base peak in 11e and 11f indicates that benzylic fragmentation is accompanied by proton transfer to the ketonic fragment from a hydroxyl group of the benzyl fragment. Methyl ketone signals in the ${ }^{1} \mathrm{H}$ NMR spectrum support the assignment of the double bond and carbonyl positions: $\delta 2.016$ and $2.024 \mathrm{ppm}$ for the non-congugated ketones 11a and 11c, $\delta 2.132 \mathrm{ppm}$ for undecan-2-one (2), and $\delta 2.239 \mathrm{ppm}$ for the congugated ketones 11b, 11d, 11e and 11 . 

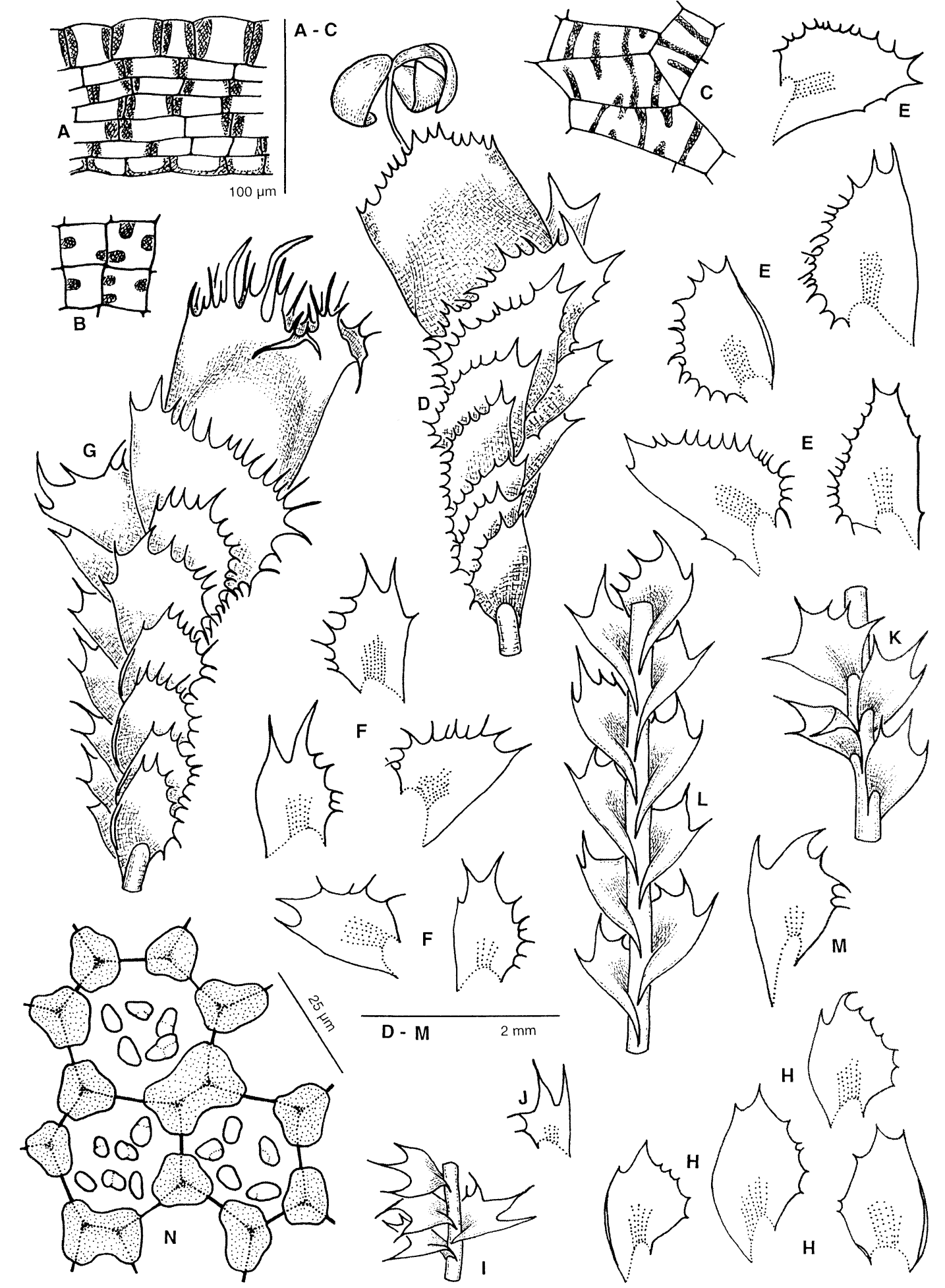


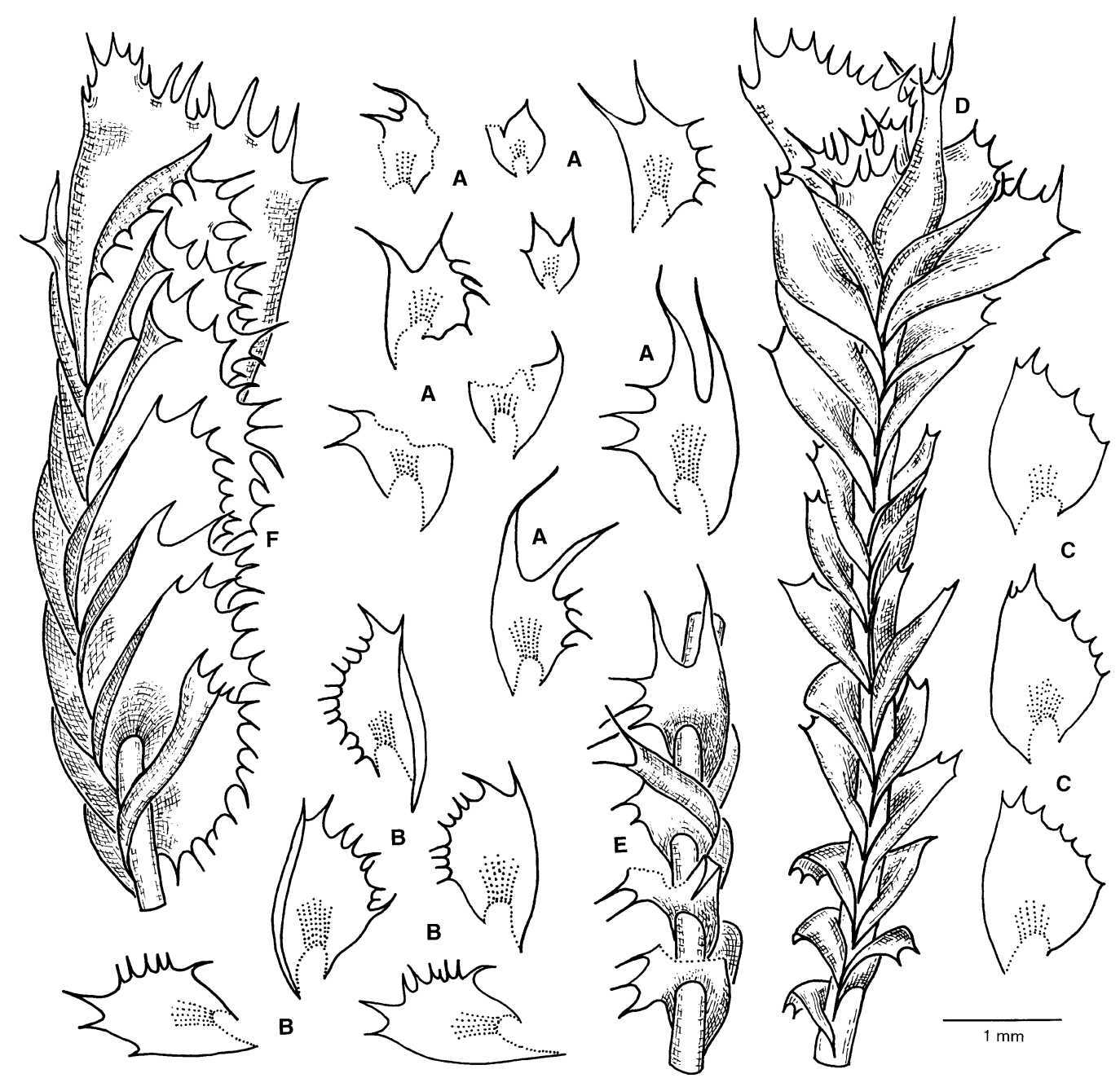

Figure 4. Plagiochila bifaria (Sw.) Lindenb. - A-C. Leaves. - D. Top of female shoot with young perianth, dorsal view. - E. Part of shoot, lateral view. - F. Top of female shoot with perianth, lateral view [A, E from Costa Rica, Heinrichs et al. 4394 (GOET); B, F from Brazil, Costa \& Gradstein 3805 (GOET); C, D from Jamaica, Swartz s.n. (G, isotype of P. bifaria)].

We have not been able to assign the configuration of the double bonds.

Both the chemical and the morphological variation of neotropical $P$. bifaria are larger than that of European $P$. bifaria. The European (including Macaronesian) populations investigated so far belong to a single chemotype, which has considerable variation in the proportions of the minor constituents, whereas at least three different chemotypes have been recognized within the Neotropical material. Morphological variation within European stands of $P$. bifaria is generally lower than within neotropical populations. Phenotypes with long-ciliate leaf teeth or distinctly elongate-triangular, sometimes lobelike apical teeth have not been observed within European gatherings.

Taxonomic treatment.-The overall impression of the molecular investigation is that the broad species concept of $P$. bifaria proposed by Heinrichs et al. $(1998 a, b)$ should be maintained. The broad morphological concept changes the status of two Plagiochila binomials. We assign $P$. compressula (Nees) Lindenb. (Figs. 3I,J) and P. centrifuga Spruce (Figs. 3K-M) as new synonyms of $P$. bifaria.

Plagiochila bifaria (Sw.) Lindenb., Spec. Hepat. 127: 1843 .

Jungermannia bifaria Sw., Prod. Nov. Gen. Spec. 145. 1788. TYPE: Jamaica, Swartz s.n. (s, holotype).

Jungermannia compressula Nees, Enum. Pl. Crypt. Jav.: 75. 1830, syn. nov. TYPE: Mexico (sTR, holotype).

Plagiochila compressula (Nees) Lindenb., Spec. Hepat. (fasc. 5): 128. 1843. 


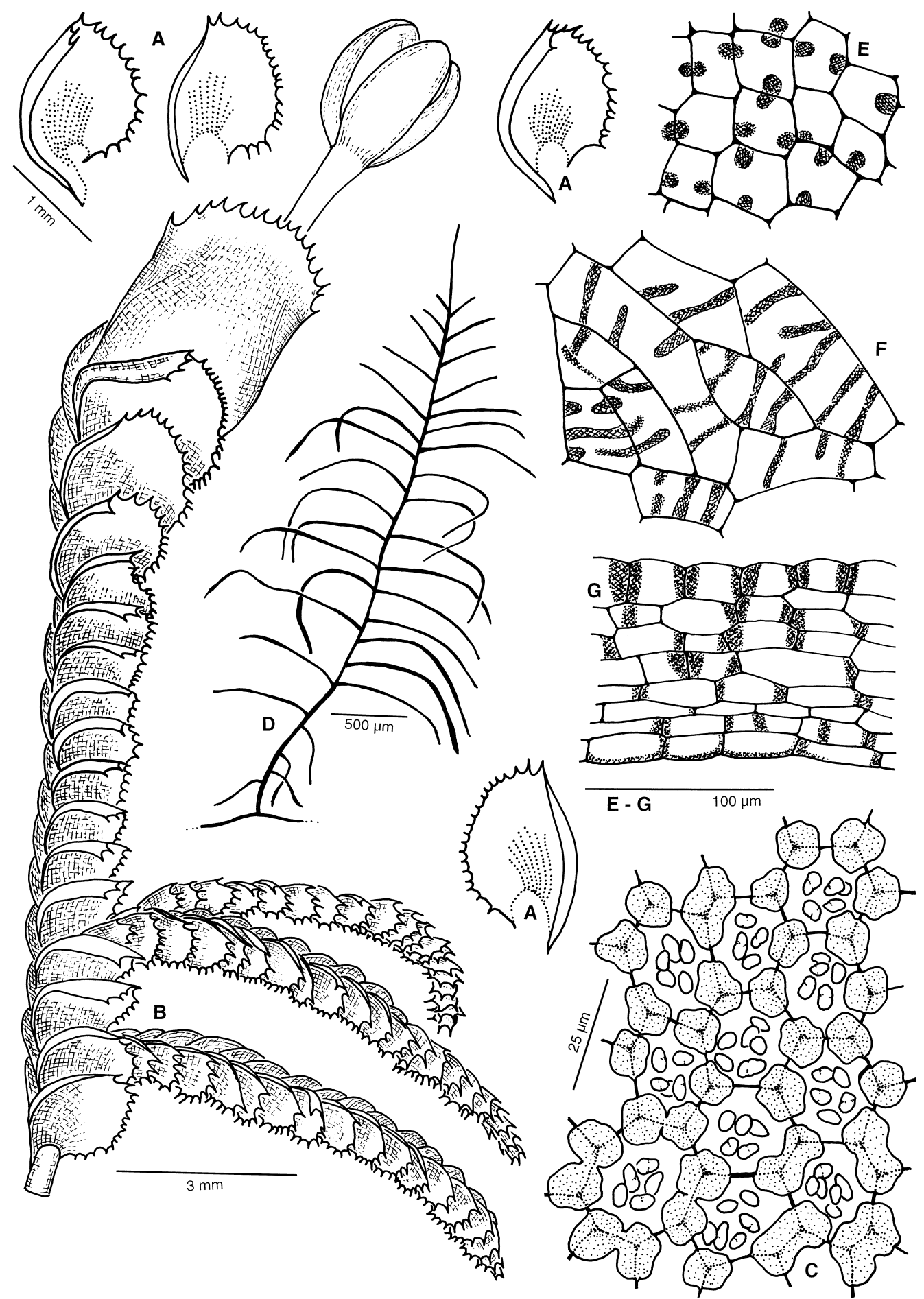

Figure 5. Plagiochila bifaria (Sw.) Lindenb. - A. Leaves. - B. Top of female shoots with sporophyte, lateral view. - C. Cells from upper leaf half with oil bodies. - D. Habit. - E. Cells from capsule wall epidermis, surface view. - F. Cells from innermost layer of capsule wall, surface view. - G. Transverse section of capsule wall [all from Bolivia, Heinrichs et al. 4402 (GOET)]. 
TABLE 2. Compounds (in order of elution on GC) and quantities (Q, expressed as mol $\mathrm{t}^{-1}$ of dry plant material extracted) present in nine $\mathrm{CDCl}_{3}$ extracts of P. bifaria (Sw.) Lindenb. The specimens (all in GOET) are: i) Heinrichs et al. 4402, Bolivia, 8 October 1997, $135 \mathrm{mg}$ extracted 9 June 1998; ii) Heinrichs et al. 4396, Bolivia, 1997, $50 \mathrm{mg}$ extracted 30 May 2003; iii) Anton et al. BOL 7, Bolivia, 1997, 42 mg extracted 14 June 2003; iv) Costa \& Gradstein 3375, Brazil, April 2000, 16 mg extracted 3 May 2000; v) Costa \& Gradstein 3711, Brazil, 2000, 29 mg extracted 4 May 2000; vi) Costa \& Gradstein 3805, Brazil, 12 April 2000, 13 mg extracted 14 July 2003; vii) Heinrichs et al. 4394, Costa Rica, 27 September 1999, 23 mg extracted 14 July 2003; viii) Holz EC-01-416, Ecuador, 2001,24 mg extracted 5 June 2001; ix) Rycroft 01024, Tenerife, 19 February 2001, 30 mg extracted 25 July 2001. Concentrations were determined from integration of $400 \mathrm{MHz}$ proton NMR spectra; '- ' indicates that a compound was not detected; 'tr.' indicates trace detected; parentheses denote detection by GC-MS only. The table includes the four most abundant compounds in each extract and in addition any compounds with $\mathrm{Q}>10 \mathrm{~mol} \mathrm{t}^{-1}$ in any extract as long as $\mathrm{Q}>15 \%$ of the most abundant compound in that extract, except that for specimen (v) there are another five compounds with $Q$ $\approx 12 \mathrm{~mol} \mathrm{t}^{-1}$ (one 9-arylnon-6-en-2-one and four 9-arylnona-3,6-dien-2-ones) for which only partial structures were elucidated (see text).

\begin{tabular}{|c|c|c|c|c|c|c|c|c|c|c|}
\hline & \multirow[b]{2}{*}{ Compound } & \multicolumn{9}{|c|}{ Specimen number } \\
\hline & & (i) & (ii) & (iii) & (iv) & (v) & (vi) & (vii) & (viii) & (ix) \\
\hline 1 & $\beta$-phellandrene & 4 & 12 & 17 & 25 & 11 & 7 & 7 & 24 & 14 \\
\hline 2 & undecan-2-one & - & - & - & - & 10 & - & - & - & - \\
\hline 3 & peculiaroxide [peak 2 in Rycroft et al. 1999] & 4 & 13 & 18 & - & - & - & - & - & 15 \\
\hline 4 & bicyclogermacrene & - & - & - & 22 & 12 & 7 & 4 & 9 & 5 \\
\hline 5 & spathulenol & - & (1) & (1) & - & - & 8 & 3 & 1 & - \\
\hline 6 & methyl everninate & - & - & - & - & - & - & - & 91 & 155 \\
\hline 7 & unknown [peak 7 in Rycroft et al. 1999] & - & - & - & - & - & - & - & 27 & 13 \\
\hline 8 & $\begin{array}{l}\text { methyl 6-hydroxy-2-methyl-3,4-methylenedioxybenzo- } \\
\text { ate }\end{array}$ & - & - & - & - & - & - & - & 17 & 5 \\
\hline 9 & $\begin{array}{l}\text { methyl 6-methoxy-2-methyl-3,4-methylenedioxybenzo- } \\
\text { ate }\end{array}$ & - & - & - & - & - & - & - & 16 & 10 \\
\hline 10 & unknown [peak 11 in Rycroft et al. 1999] & - & - & - & - & - & - & - & 43 & 13 \\
\hline $11 \mathrm{a}$ & 9-(4-methoxyphenyl)non-6-en-2-one & - & - & - & - & 13 & - & - & - & - \\
\hline 12 & 3,5-dimethoxy-9,10-dihydrophenanthren-2-ol & 9 & 33 & 51 & 27 & - & 6 & 15 & 4 & 2 \\
\hline 13 & 2,3,5-trimethoxy-9,10-dihydrophenanthrene & 0.3 & 2 & 3 & 9 & - & 9 & 1 & - & - \\
\hline 14 & 3-methoxy-9,10-dihydrophenanthrene-4,5-diol & - & - & - & - & - & - & - & 14 & 5 \\
\hline 15 & 3,7-dimethoxy-9,10-dihydrophenanthren-2-ol & 0.2 & 1 & 1 & 11 & - & 2 & 1 & - & - \\
\hline 16 & methyl 4-hydroxy-4'-O-methyllunularate & 3 & 9 & 10 & 12 & - & 6 & 4 & - & - \\
\hline 17 & 3,7-dimethoxy-9,10-dihydrophenanthren-4-ol & - & - & - & tr. & - & - & 4 & - & - \\
\hline 18 & 2,3,7-trimethoxy-9,10-dihydrophenanthrene & - & - & - & 11 & - & 6 & tr. & - & - \\
\hline 19 & killarniensolide & - & - & - & - & - & - & - & 28 & 21 \\
\hline
\end{tabular}

Plagiochila centrifuga Taylor ex Spruce, Trans. \& Proc. Bot. Soc. Edinburgh 15: 484. 1885, syn. nov. TYPE: Ecuador, Quito, Jameson 1334 (G, syntype); Mt. Azuay, Spruce s.n. (G, syntype).

Representative specimens examined.-BOLIVIA. Coснавамва. Carrasco, between Pojo and La Siberia, 2,600-2,700 m, Heinrichs et al. 4075 (GOET, LPB); LA PAZ. Nor Yungas, $3 \mathrm{~km}$ NE of Unduavi, 3,400 m, Heinrichs et al. 4402 (GOET, LPB). BRAZIL. Rio DE JANEIRO. P.N. Itatiaia, Riacho Campo Belo, 2,400 m, Costa \& Gradstein 3805 (GOET, RB). BRITISH ISLES. SCOTLAND. The Trossachs, West Perthshire, 220 m, Rycroft 01014 (GOET). COLOMBIA. Santander. Las Vegas, 2,600-3,000 m, Killip \& Smith 16125 (JE). MEXICO. Iztaccihuatl, 4,000 m, Cleef \& Delgadillo 10275b (GOET, U). COSTA RICA. SAN José. San Gerardo de Dota, 2,000 m, Heinrichs et al. 4394 (GOET, INB). CUBA. ORIENTE. Sierra Maestra, 1,300-1,800 m, Bisse \& Lippold 19921 (JE). ECUADOR. GALAPAGOS IsLs. Cristóbal, NE of El Junco, 500 m, Eliasson \& Eliasson 1858 (GOET, U); ZAMORA-CHINCHIPE. Estación Cientifica San Francisco on highway from Loja to Zamora, 1,850-2,200 m, Holz EC-01-113 \& 416 (GOET). JAMAICA. John Crow Peak, 1,800 m, Underwood 787 (GOET, NY). PANAMA. ChIRIQuí. WNW of Boquete, Chiriquí volcano, 1,900-2,000 m, Davidse \& D'Arcy $10160 G$ (GOET, U). PERU. Cuzco. Paucartambo, Challabamba,
2,800 m, Inoue s.n. (G, Bryoph. Sel. Exs. 866). PORTUGAL. MADEIRA. between Portela and Ribeiro Frio, 650$750 \mathrm{~m}$, Drehwald \& Reiner-Drehwald 3010 (GOET, Bryoph. Exs. Gen. Plag. 19). SPAIN. TeneriFE. Montañas de Anaga, 750 m, Drehwald 3922 (GOET, Bryoph. Exs. Gen. Plag. 164). VENEZUELA. Bolivar. Mt. Roraima, $1,950 \mathrm{~m}$, Buck \& Brewer 15662 (GOET, NY).

Plagiochila bifaria is widespread in mountainous regions of the Neotropics from Mexico southwards to Bolivia and southeastern Brazil and also occurs in Atlantic Europe including Macaronesia (Fig. 7). In the Neotropics the species grows in moist forests and shrubby communities of the subparamo at elevations between 500 and 4,200 m, often as an epiphyte on trunks, branches, and twigs.

\section{DisCUSSION}

Acceptance of high levels of morphological and phytochemical variation and broad distributions of bryophyte species may result in lumping nonmonophyletic units, especially in groups such as Plagiochila that have few characters. However, sequencing variable regions of chloroplast or nuclear 
<smiles>C=C1C=CC(C(C)C)CC1</smiles>

1

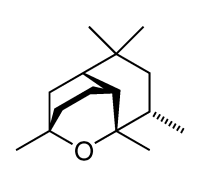

3<smiles>CC1=CCC2(CC2(C)C)C(C)CCC1</smiles>

4<smiles>C=C1CC[C@@H]2[C@@H]([C@@H]3[C@H]1CC[C@@]3(C)O)C2(C)C</smiles>

5<smiles>COC(=O)c1c(C)cc(OC)cc1O</smiles>

6<smiles>COC(=O)c1c(OCO)cc2c(c1C)OCO2</smiles>

8<smiles>COC(=O)c1c(OC)cc2c(c1C)OCO2</smiles>

9<smiles>CCCCCCCCCC(C)=O</smiles><smiles>COc1ccc(CC/C=C/CCCC(C)=O)cc1</smiles><smiles>COc1cc2c(cc1O)CCc1cccc(OC)c1-2</smiles><smiles>COc1cc2c(cc1OC)-c1c(cccc1OC)CC2</smiles>

13<smiles>COc1ccc2c(c1O)-c1c(O)cccc1CC2</smiles>

14<smiles>COc1ccc2c(c1)CCc1cc(OC)c(OC)cc1-2</smiles>

FIGURE 6. Chemical structures, identified by the bold numerals that are used in the text and Table 2 .

ribosomal DNA has proved to be a powerful tool to test species concepts and to reconstruct dispersal events (e.g., McDaniel \& Shaw 2003; Shaw et al. 2002).
High infraspecific ITS variation seems to be common in bryophytes and is evident for several genera and families e.g., Amblystegiaceae (Vanderpoorten et al. 2001); Bryum (Longton \& Hedderson

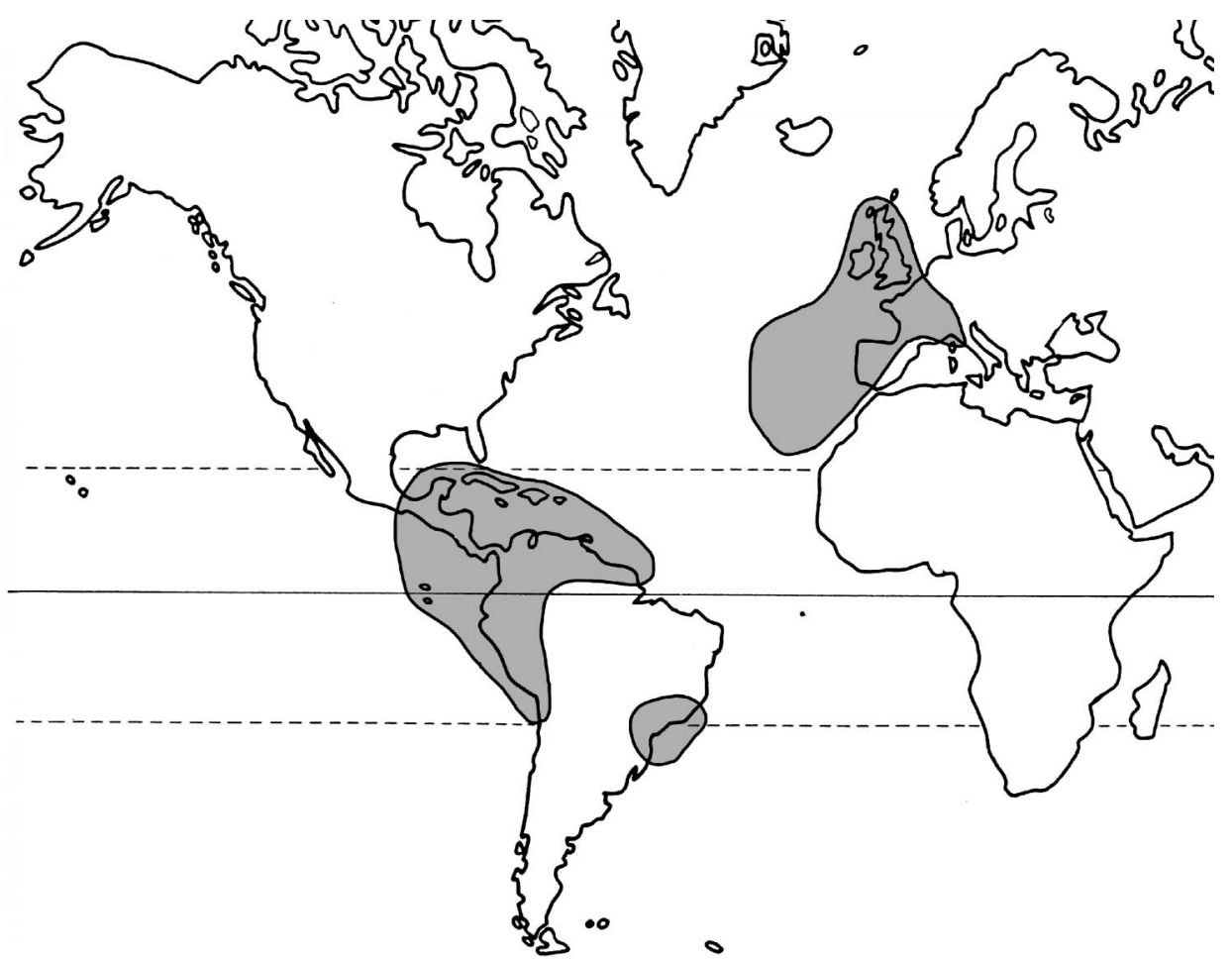

Figure 7. Distribution of P. bifaria (Sw.) Lindenb. 
2000); Fontinalis (Shaw \& Allen 2000); Hylocomium (Chiang \& Schaal 1999); Mielichhoferia (Shaw 2000); and Plagiochila (Heinrichs 2002; Heinrichs et al. 2003; Rycroft et al. 2002). ITS variation in some genera of mosses is so high that sequences cannot be aligned successfully (Shaw et al. 2002; Vanderpoorten et al. 2001). Other studies of moss species indicate that morphologically inseparable units are poly- or paraphyletic, e.g., Fontinalis antipyretica Hedw. (Shaw \& Allen 2000) and Hygroamblystegium tenax (Hedw.) C.Jens. (Vanderpoorten et al. 2001). Morphological species concepts in Plagiochila have been confirmed so far by phylogenetic analyses of nrITS sequence variation (Groth et al. 2003). In addition, the topologies obtained from the nrITS region are largely congruent with those resulting from analyses of chloroplast markers ( $r p s 4, r b c \mathrm{~L}$; Groth \& Heinrichs, unpublished).

Similar ITS sequences from representatives of Plagiochila sect. Arrectae from Europe and the neotropics indicate rapid morphological diversification of the group and suggest distribution by long distance dispersal events. Sporophytes of $P$. bifaria were observed by DSR on Madeira in 1999, occur frequently within Azorean populations (Bates \& Gabriel 1997), and are often present in neotropical specimens. The maximum likelihood analysis of the $P$. bifaria sequences from Europe and the neotropics did not result in separate clades, supporting a relatively recent spore dispersal event between both floristic kingdoms. The more uniform morphology of European $P$. bifaria may be the result of less favorable growing conditions (limiting the number of viable ecotypes) or a few dispersal events originating from a Neotropical population.

The lack of the $20 \mathrm{bp}$ sequence at the end of ITS1 within some of the $P$. bifaria sequences is further support for the sister relationship of the $P$. sects. Arrectae and Rutilantes, which is inferred not only from phylogenetic analyses of ITS sequences (e.g., Groth et al. 2002, Heinrichs et al. 2002a) but also from large overlap in secondary metabolite composition (Anton 2001) and morphology (oil bodies, branching pattern, sporophyte, see Groth et al. 2002, Heinrichs 2002, Heinrichs et al. 2002a).

The phytochemical profiles in Table 2 demonstrate that there are at least three chemotypes within neotropical material of $P$. bifaria. Specimens (i)(iv), (vi), and (vii) are characterized by a range of 9,10-dihydrophenanthrenes (e.g., 12), specimen (viii) by a large amount of methyl everninate (6), and specimen (v) by several 9-arylnon-6-en-2-ones (e.g., 11a). The methyl everninate chemotype is also present in Europe (including Macaronesia). It was noted previously (Rycroft et al. 1999) that two of the minor compounds (8 and 9) in the methyl everninate chemotype were particularly weak in material from the Azores in comparison to Scottish material. It can now be seen that this is not a Macaronesian characteristic as the Tenerife specimen (ix) (as well as Madeiran material and other European material not presented in detail here) has a phytochemical profile similar to that of Scottish material. By quantifying the amounts of compounds present in the plant extracts it can be seen that the dominating position of methyl everninate exists because of high levels of this compound rather than low levels of the other constituents.

Although the benzenoid compounds in the 9-arylnon-6-en-2-one chemotype specimen (v) appear radically different from those in the other specimens, the nonylbenzene carbon skeleton of these compounds is in fact the same as that of compounds thought to be involved in the biosynthesis of lunularic acid, bibenzyls, and 9,10-dihydrophenanthrenes, as has been demonstrated in the case of cyclic bis(bibenzyl) biosynthesis in Marchantia polymorpha L. (Friederich et al. 1999). It is possible that only relatively minor changes to biosynthetic pathways are required for 9-arylnon-6-en-2-ones to be produced rather than the other aromatic compounds in Table 2. The earlier phytochemical study of $P$. bifaria (Rycroft et al. 1999) noted that the GC-MS profile reported by Asakawa and Inoue (1987) for a Peruvian specimen demonstrated that it was chemically distinct from European material. The major component of the GC-MS profile was reported to have molecular mass 274 (base peak 151); it is possible that this refers to compound 11d and that the Peruvian specimen (Inoue 34048) belongs to the 9-arylnon-6-en-2-one chemotype.

The similarity between the profiles of specimens (i)-(iii) and those of some examples of P. retrorsa reinforces the observation made in earlier studies (Heinrichs et al. 2002c; Rycroft et al. 2001) that phytochemical profiles cannot necessarily provide unambiguous species identification.

The well-supported subclade (Fig. 1) containing ITS sequences from the British, Tenerife, and Ecuadorian specimens is congruent with the methyl everninate chemotype in so far as the chemistry has been studied (specimen Holz EC-O1-113 was not analyzed chemically). The evidence shows there is no case to establish a variety based on regional distributions and chemistry. In view of the morphological differences exhibited by the specimen Holz EC-01-113 (compared to the other specimens in the subclade), evidence does not support establishment of a variety based on congruence of the chemical differences with the phylogenetic subclade.

\section{ACKNOWLEDGMENTS}

We are grateful to the curators and directors of the herbaria cited in the text for the loan of specimens, to Monica 
Moraes and Stefan Beck (Herbario Nacional de Bolivia) for logistic support during fieldwork in Bolivia, to John Cole and Jim Tweedie (University of Glasgow) for GCMS experiments, and to Catherine La Farge and an anonymous reviewer for constructive comments on an earlier version of this paper. The study was supported by the Deutsche Forschungsgemeinschaft (grant DFG HE 3584/ $1)$.

\section{Literature Cited}

Akaike, H. 1974. A new look at the statistical model identification. IEEE Transactions on Automatic Control 19: 716-723.

Anton, H. 2001. Neue Ergebnisse zur Chemie und Chemotaxonomie der Plagiochilaceae (Lebermoose). Ph.D. Dissertation, University of the Saarland, Saarbrücken.

Asakawa, Y. \& H. Inoue. 1987. Chemical constituents of Peruvian Plagiochila species, pp. 119-128. In H. Inoue (ed.), Studies on Cryptogams in Southern Peru. Tokai University Press, Tokyo.

Bates, J. W. \& R. GABriel. 1997. Sphagnum cuspidatum and $S$. imbricatum ssp. affine new to Macaronesia, and other new island records for Terceira, Azores. Journal of Bryology 19: 645-648.

Chiang, T. Y. \& B. A. SchaAl. 1999. Phylogeography of North American populations of the moss species $\mathrm{Hy}$ locomium splendens based on the nucleotide sequence of internal transcribed spacer 2 of nuclear ribosomal DNA. Molecular Ecology 8: 1037-1042.

Felsenstein, J. 1985. Confidence limits on phylogenies: an approach using the bootstrap. Evolution 39: 783 791.

Friederich, S., U. H. Maier, B. Deus-Neumann, Y. AsaKAWA \& M. H. ZenK. 1999. Biosynthesis of cyclic bis(bibenzyls) in Marchantia polymorpha. Phytochemistry 50: 589-598.

GotTsche, C. M. 1863-1867. De mexicanske Levermosser. Copenhagen.

Groth, H., F. A. Hartmann, R. Wilson \& J. Heinrichs. 2004: nrITS sequences and morphology indicate a synonymy of the Patagonian Plagiochila rufescens Steph. and the Central American Plagiochila bicuspidata Gottsche. Cryptogamie, Bryologie 25 (in press).

- G. Helms \& J. Heinrichs. 2002. The systematic status of Plagiochila sects. Bidentes Carl and Caducilobae Inoue (Hepaticae) inferred from nrDNA ITS sequences. Taxon 51: 675-684.

- M. Lindner, R. Wilson, F. A. Hartmann, M. Schmull, S. R. Gradstein \& J. HeinRichs. 2003. Biogeography of Plagiochila (Hepaticae): natural species groups span several floristic kingdoms. Journal of Biogeography 30: 965-978.

HALl, T. A. 1999. BioEdit: a user-friendly biological sequence alignment editor and analysis program for Windows 95/98/NT. Nucleic Acids Symposium Series 41: 95-98.

Hasegawa, M., H. Kishino \& T. Yano. 1985. Dating the human-ape splitting by a molecular clock of mitochondrial DNA. Journal of Molecular Evolution 22: 160-174.

HeInRichs, J. 2002. A taxonomic revision of Plagiochila sect. Hylacoetes, sect. Adiantoideae and sect. Fuscoluteae in the Neotropics with a preliminary subdivision of neotropical Plagiochilaceae into nine lineages. Bryophytorum Bibliotheca 58: 1-184, Append. 1-5. \& H. Anton. 2001. Bryophyta Exsiccata Generis Plagiochilae, a new exsiccata distributed by the Uni- versity of Göttingen herbarium. Polish Botanical Journal 46: 109-111.

- H. Anton, S. R. Gradstein \& R. Mues. 2000. Systematics of Plagiochila sect. Glaucescentes Carl (Hepaticae) from tropical America: a morphological and chemotaxonomical approach. Plant Systematics and Evolution 220: 115-138.

- S. R. GRAdSTEIN \& R. GRolle. 1998a. A revision of the neotropical species of Plagiochila (Dumort.) Dumort. (Hepaticae) described by Olof Swartz. Journal of the Hattori Botanical Laboratory 85: 1-32.

, S. R. Gradstein, H. Groth \& M. Lindner. 2003. Plagiochila cucullifolia var. anomala var. nov. with notes on discordant molecular and morphological variation in Plagiochila. Plant Systematics and Evolution 242:205-216.

, R. Grolle \& U. Drehwald. 1998b. The conspecificity of Plagiochila killarniensis Pearson and P. bifaria (Sw.) Lindenb. (Hepaticae). Journal of Bryology 20: 495-497.

, H. Groth, I. Holz, D. S. Rycroft, C. RenKer \& T. PRÖSCHOLD. 2002a. The systematic position of Plagiochila moritziana, P. trichostoma and P. deflexa, based on ITS sequence variation of nuclear ribosomal DNA, morphology and lipophilic secondary metabolites. The Bryologist 105: 189-203.

, T. Pröschold, C. Renker, H. Groth \& D. S. RYCROFT. 2002b. Plagiochila virginica A. Evans rather than $P$. dubia Lindenb. \& Gottsche occurs in Macaronesia; placement in sect. Contiguae Carl is supported by ITS sequences of nuclear ribosomal DNA. Plant Systematics and Evolution 230: 221-230.

, D. S. Rycroft, H. Groth \& W. J. Cole. $2002 c$. Morphological and phytochemical studies of Plagiochila papillifolia Steph., a Neotropical liverwort new to Europe. Journal of Bryology 24: 119-126.

Longton, R. E. \& T. A. HedDERSON. 2000. What are rare species and why conserve them? Lindbergia 25: 5361.

McDaniel, S. \& A. J. Shaw. 2003. Phylogeographic structure and cryptic speciation in the trans-antarctic moss Pyrrhobryum mnioides. Evolution 57: 205-215.

Posada, D. \& K. A. Crandall. 1998. Modeltest: testing the model of DNA substitution. Bioinformatics 14: $817-818$.

RYCROFT, D. S. 1999. A chemist's view of liverworts: NMR fingerprinting and chemotype classification of British Plagiochilae. Bulletin of the British Bryological Society 72: 50-54.

. 2003. Chemosystematics and the liverwort genus Plagiochila. Journal of the Hattori Botanical Laboratory 93: 331-342.

, W. J. Cole, N. Aslam, Y. M. Lamont, \& R. GaBRIEL. 1999. Killarniensolide, methyl orsellinates and 9,10-dihydrophenanthrenes from the liverwort Plagiochila killarniensis from Scotland and the Azores. Phytochemistry 50: 1167-1173.

- W. J. Cole, J. Heinrichs, H. Groth, C. Renker \& T. PRÖSCHOLD. 2002. Phytochemical, morphological and molecular evidence for the occurrence of the Neotropical liverwort Plagiochila stricta in the Canary Islands, new to Macaronesia. THE BRYOLOGIST 105: 363-372.

, J. Heinrichs, W. J. Cole \& H. Anton. 2001. A phytochemical and morphological study of the liverwort Plagiochila retrorsa Gottsche, new to Europe. Journal of Bryology 23: 23-34.

SAiki, R. K., D. H. Gelfand, S. Stoffel, S. J. Scharf, R. Higuchi, G. T. Horn, K. B. Mullis \& H. A. Ehrlich. 
1988. Primer-directed enzymatic amplification of DNA with a thermostable DNA polymerase. Science 239: 487-491.

SHAw, A. J. 2000. Molecular phylogeny and cryptic speciation in the mosses, Mielichhoferia elongata and $M$. mielichhoferiana (Bryaceae). Molecular Ecology 9: 595-608.

\& B. H. AlLEN. 2000. Phylogenetic relationships, morphological incongruence, and geographic speciation in the Fontinalaceae (Bryophyta). Molecular Phylogenetics and Evolution 16: 225-237.

, S. F. McDaniel, O. Werner \& R. M. Ros. 2002. Phylogeography and phylodemography. THE BRYOLOGIST 105: 373-383.

SÖDERSTRÖM, L., E. URMI \& J. VÁŇA. 2002. Distribution of Hepaticae and Anthocerotae in Europe and Macaronesia. Lindbergia 27: 3-47.
SPRUCE, R. 1884-1885. Hepaticae of the Amazon and the Andes of Ecuador and Peru. Transactions and Proceedings of the Botanical Society of Edinburgh 15: ixi, $1-589$, plates $\mathrm{i}-\mathrm{xxii}$.

Stephani, F. 1902-1905. Plagiochila Dum. Species Hepaticarum 2: 195-595. Geneva.

Swofford, D. L. 2000. PAUP*, Phylogenetic Analysis using Parsimony (*and Other Methods). Sinauer Associates, Sunderland, MA.

Vanderpoorten, A., A. J. Shaw \& B. Goffinet. 2001. Testing controversial alignments in Amblystegium and related genera (Amblystegiaceae: Bryopsida). Evidence from rDNA ITS sequences. Systematic Botany 26: 470-479.

ms. received Aug. 15, 2003; accepted Oct. 28, 2003. 